\title{
Mycetoma fungal infection: multiple organisms as colonizers or pathogens?
}

\author{
Infecção fúngica por micetoma: organismos múltiplos \\ como patógenos ou colonizadores?
}

\author{
Florian H. Pilsczek ${ }^{1,2}$ and Michael Augenbraun ${ }^{1}$
}

\begin{abstract}
We describe a patient with mycetoma or Madura foot, in which histopathological stains of the bone and surface cultures suggested three different organisms including Nocardia species as the cause. Criteria for the diagnosis of the organisms, differentiation between colonizer and pathogen, and significance of mixed infections are discussed.
\end{abstract}

Key-words: Mycetoma. Madura foot. Colonization.

\section{RESUMO}

Descrevemos um paciente com micetoma ou maduromicose de pé, no que colorações histopatológicos de osso e de culturas superficiais sugeriram três organismos diferentes, incluindo espécies de Nocardia como causador. Os critérios de diagnóstico dos organismos, a diferenciação entre colonizador e patógeno, e a significância das infecções mistas são discutidos.

Palavras-chaves: Micetoma. Maduromicose de pé. Colonização.

Mycetoma is a chronic progressive granulomatous infection of the skin and subcutaneous tissue that usually affects the foot and leg. The typical clinical appearance is swelling with sinus tracts draining the organism as grains or granules ${ }^{16}$. The two main forms are eumycetoma or Madura foot, caused by fungi such as Madurella spp, Leptoshaeria spp, Curvularia spp, Exophiala jeanselmei, Phialophora verrucosa, Pyrenochaeta mackinnonii, P. romeroi, Pseudallescheria boydii (Scedosporium apiospermum), Acremonium spp, Aspergillus spp, Fusarium spp. and Neotestudina rosatii; and actinomycetoma, caused by filamentous higher bacteria such as Actinomadurae madurae, Nocardia spp, Streptomyces somaliensis and Actinomadurae pelletier $i^{17}$.

Here we describe a patient from Jamaica who, from the clinical appearance of the foot and leg, had an infection due to eumycetoma or Madura foot. However, bone biopsy histology and different cultures suggested more than one organism as the cause of the infection.

The criteria for diagnosing the organisms and differentiating between colonizer and pathogen, and the significance of mixed infections, are discussed.

\section{CASE REPORT}

A 55-year-old Jamaican woman with a chronic right leginfection for 16 years was seen at the outpatient clinic. She lived in a rural area and was involved in farming in Jamaica, and in 1993 she had had a draining lesion of the foot that was treated with surgery and unknown medication. Surgery was repeated in 2002 and she was told that she had Madura foot. The patient visited our outpatient clinic even though there had been no change in her condition. Physical examination showed chronic skin changes on the leg, with swelling and yellow fluid-draining sinuses (Figure 1).

Hematoxylin and eosin (H \& E) staining of a bone biopsy specimen showed inflammatory exudates containing organisms suggestive of Nocardia species (Figure 2). Anaerobic culturing of the bone biopsy specimen grew Propionibacterium granulosum and Propionibacterium acnes with scant growth, and other bacterial and fungal cultures with standard media were negative. Bacterial culturing before the procedure grew methicillin-sensitive

\footnotetext{
1. Division of Infectious Disease, SUNY Downstate Medical Center, Brooklyn, New York, USA. 2. Max-Planck Institute for Infection Biology, Department of Immunology, Berlin, FRG Address to: Dr. Pilsczek Max Planck. Dept of Immunology/Institute for Infection Biology, 10117 Berlin, FRG.

Tel: 4930 2846-0538: Fax: 4930 2846-0505

e-mail: f.h.pilsczek@gmail.com

Recebido em: 14/11/2006

Aceito em: 08/02/2007
} 
Staphylococcus aureus (sensitive to ceftriaxone, clindamycin, erythromycin, gatifloxacin, gentamicin, oxacillin, rifampin, tetracycline, trimethoprim-sulfamethoxazole and vancomycin).

Intravenous treatment in hospital was not possible and the patient was therefore treated with oral trimethoprimsulfamethoxazole and doxycycline.

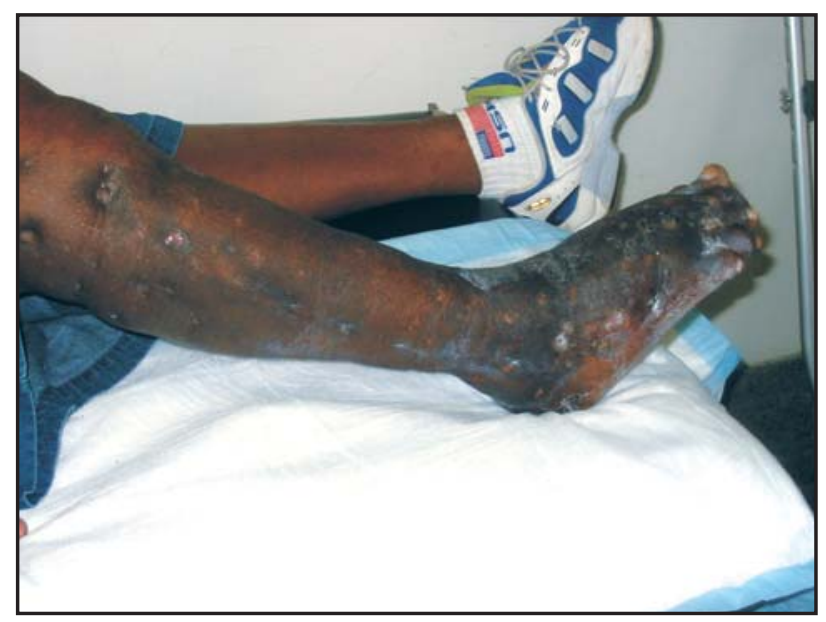

Figure 1 - Madura foot. Extensive involvement of the foot and leg can be seen with chronic skin abnormalities and scattered openings of sinuses draining yellow fluid.

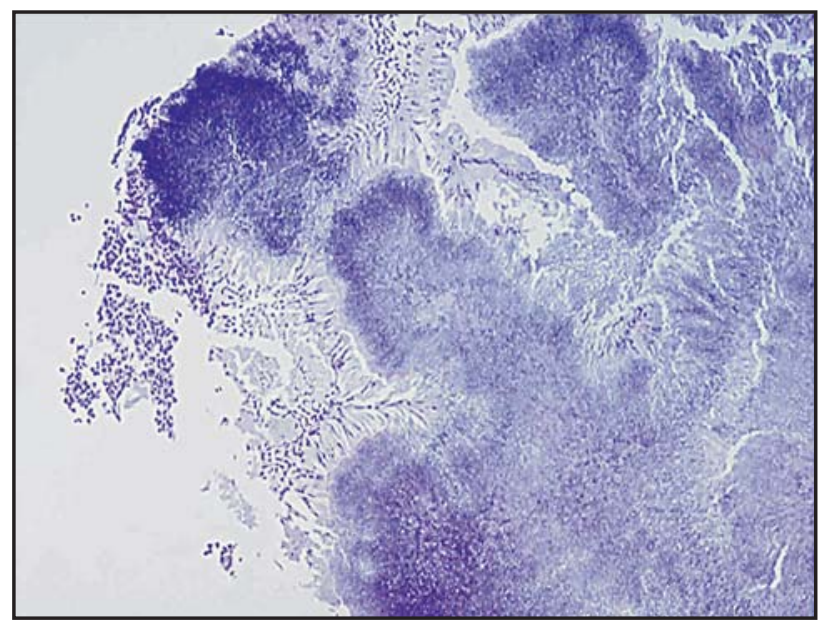

Figure 2 - Histological stain of bone specimen. A representative stained section of the biopsy from the foot is presented and clusters of inflammatory cells and organisms can be seen. H\&E 40X.

\section{DISCUSSION}

In this patient, the diagnosis of infection with Nocardia species was suggested by the histological appearance of the exudates, which contained organisms that stained with $\mathrm{H}$ \& $\mathrm{E}$ (Figure 2). In Gram-stained histological sections, infection with Nocardia species appears as a pyogenic tissue reaction with large suppurative abscesses containing Gram-positive branched filamentous hyphae ${ }^{89}$. The diameter of the organism is 0.5 to $1 \mu \mathrm{m}$ and up to $20 \mu \mathrm{m}$ in length. In mycetomas, compact granules similar to those found with anaerobic actinomycetes are formed. The $\mathrm{H} \& \mathrm{E}$ staining demonstrates the tissue reaction and the granules, but does not stain the individual filaments. Acid-fast staining is positive for Nocardia asteroides, Nocardia brasiliensis, and Nocardia otitidiscaviarum $^{23610}$.

Propionibacterium is a Gram-positive, anaerobic, nonspore-forming rod. The bowel mucosa is inhabited by different Propionibacterium species, and Propionibacterium acnes and other Propionibacterium spp are part of the normal flora of the skin, nasopharynx, oral cavity, and genitourinary $\operatorname{tract}^{\dagger}$ Although usually nonpathogenic for humans, different documented cases of infection (e.g. in association with implanted prostheses or central nervous system shunts) have been reported ${ }^{714}$ Propionibacterium acnes has also been identified as a frequently recovered cause of anaerobic arthritis in association with prosthetic joints, vascular disease, and peripheral neuropathy. Isolation of these microorganisms from patients with osteomyelitis has been reported $^{7}$. In the present case, it was difficult to decide whether the cultured Propionibacterium species were pathogens, since no defined diagnostic criteria are available. The clinical criteria suggestive of an infection are repeatedly positive cultures, no other infectious organism identified, and an immunocompromised host. However, in the present patient, since there was a possibility that the identified Propionibacterium species had contributed towards a chronic infection, the treatment may have been appropriate.

Staphylococcus aureus was grown from superficial cultures and not from the specimen obtained during biopsy. Staphylococcus aureus is a common cause of chronic osteomyelitis. However, one fact that did not support the hypothesis of osteomyelitis due to Staphylococcus aureus was the long course of the infection, the presence of draining sinuses and the histological appearance of the bone. The histopathological changes in chronic osteomyelitis secondary to Staphylococcus species are osteoclastic bone resorption, ingrowth of fibrous tissue and deposition of reactive bone in the periphery. Reactive woven or lamellar bone may be deposited, and when it forms a sleeve of living tissue around a segment of devitalized bone, it is known as an involucrum ${ }^{9}$. A rare form of chronic infection caused by Staphylococcus aureus called botryomycosis may cause unusual histological changes with the formation of grains ${ }^{511}$. In the present case, since the bone histology is suggestive of infection with Nocardia species and histological changes due to chronic bacterial osteomyelitis are absent, it is likely that the cultured Staphylococcus aureus is a contaminant. Nonetheless, because the organism is a common cause of bone infection, treatment is advisable.

The occurrence of multiple organisms together as the cause of an infectious disease has been recognized in cases of intra-abdominal infections such as cholecystitis ${ }^{18}$ and skin and tissue infections such as pressure sores ${ }^{20}$. It may however not always be certain that cultured organisms are pathogens and not contaminants. Some single organisms may, for example, grow more efficiently than others on a culture plate and may prevent the growth of other organisms, while not being the organism responsible at the site of the patient's infection. The literature search did not identify guidelines or studies with advice on how to differentiate colonizers from pathogens, other than by means of clinical judgment (e.g. multiple positive cultures, clinical presentation or disease severity). Another aspect of the infections 
caused by multiple organisms is the possibility of a synergic effect in which, during coinfection, multiple organisms have an increased or decreased effect on the clinical criteria (e.g. fever or wound healing) and outcome. For example, coinfection can occur when Ixodes scapularis ticks transmit not only Borrelia burgdorferi (causing Lyme disease), but also transmit Babesia microti, the cause of babesiosis, and Anaplasma phagocytophilum, the cause of anaplasmosis or human granulocytic ehrlichiosis. Coinfection with these tick-borne agents may cause more severe and acute illness and the frequency of coinfection has been reported to be between $2-39 \%{ }^{19}$. For protozoic organisms, mixed-species malaria infections with Plasmodium vivax and Plasmodium falciparum infections as coinfections have been reported to cause both less and more severe disease than single-species infection, including higher fever. Most estimates describe the frequency of mixed infections to be $0.3-0.7 \%$, except for one report from Thailand that reported one-third of malaria infections to be mixed infections ${ }^{12}$. Clinicians may not always be aware of the possibility that more than one infectious organism may be responsible for an infection, since current clinical training favors assigning the manifestations of a disease to a single cause ${ }^{8}$.

Conclusion: The infection of the leg presented in this case report may have been caused by coinfection with multiple organisms. In view of the limited diagnostic information, treatment of all organisms had to be considered. No other case reports or studies were identified that could have given guidance for distinguishing between colonizers and pathogens. For most organisms, it is unknown whether coinfection with more than one organism can affect disease severity.

\section{REFERENCES}

1. Ahmed AO, van Leeuwen W, .van de Fahal SWA, Verbrugh H, van Belkum A. Mycetoma caused by Madurella mycetomatis: a neglected infectious burden. The Lancet Infectious Diseases 4:566-574, 2004.

2. Brown JM. Nocardia, Rhodococcus, Gordona, Actinomadura, Streptomyces, and other aerobic actinomycetes. In: Murray PR (ed) Manual of Clinical Microbiology. ASM Press, Washington, DC p. 502-531, 2003.

3. Brown-Elliott BA, Brown JM, Conville PS, Wallace Jr RJ. Clinical and Laboratory Features of the Nocardia spp. Based on Current Molecular Taxonomy. Clinical Microbiology Reviews 19:259-282, 2006.
4. Fahal AH. Mycetoma: a thorn in the flesh. Transactions of the Royal Society of Tropical Medicine and Hygiene 98:3-11, 2004.

5. Fain 0, Mathieu E, Chapel F Guettier C, Thomas M. Botryomycosis. Clinical Infectious Diseases 24:557-717, 1997.

6. Foltz KD, Fallat LM. Madura foot: atypical finding and case presentation. Journal of Foot and Ankle Surgery 43:327-331, 2004.

7. Goldstein EJC, Citron DM, Merriam CV, Warren YA, Tyrrell KL, Fernandez HT. Comparative in vitro activities of retapamulin (SB-275833) against 141 clinical isolates of Propionibacterium spp., including $117 \mathrm{P}$-acnes isolates. Antimicrobial Agents and Chemotherapy 50:379-381, 2006.

8. Hilliard AA, Weinberger SE, Tierney LM, Midthun DE, Saint S. Clinical problemsolving. Occam's razor versus Saint's Triad. The New England Journal of Medicine 350:599-603, 2004.

9. Kumar V, Abbas AK, Fausto N. Robbins and Cotran Pathologic basis of disease. Elsevier Saunders, Philadelphia, 2005.

10. Lexier R, Walmsley SL. Successful treatment of Madura foot caused by Pseudallescheria boydii with Escherichia coli superinfection: a case report. Canadian Journal of Surgery 42:307-309, 1999.

11. Machado CR, Schubach AO, Conceicão-Silva F, Quintella LP, Lourenço MCS, Carregal E, Valle ACF. Botryomycosis. Dermatology 211:303-304, 2005.

12. McKenzie FE, Smith DL, O'Meara WP, Forney JR, Magill AJ, Permpanich B, Erhart L.M, Sirichaisinthop J, Wongsrichanalai C, Gasser Jr RA. Fever in patients with mixed-species malaria. Clinical Infectious Diseases 42:1713-1718, 2006.

13. Nenoff P, Haustein UF, Hittel N. Activity of nadifloxacin (OPC-7251) and seven other antimicrobial agents against aerobic and anaerobic Gram-positive bacteria isolated from bacterial skin infections1. Chemotherapy 50:196-201, 2004.

14. Pan SC, Wang JT, Hsueh PR, Chang SC. Endocarditis caused by Propionibacterium acnes: an easily ignored pathogen. The Journal of Infection 51:e229-e231, 2005.

15. Pang KR, Wu JJ, Huang DB, Tyring SK. Subcutaneous fungal infections. Dermatology Therapy 17:523-531, 2004.

16. Queiroz-Telles F, McGinnis MR, Salkin I, Graybill JR. Subcutaneous mycoses. Infectious Diseases Clinical North American 17:59-85, 2003.

17. Sakavama K, Kidani T, Sugawara Y, Fujibuchi T, Mivawaki J, Miyazaki T, Yamamoto H. Mycetoma of foot: a rare case report and review of the literature. Journal of Foot and Ankle Surgery 25:763-767, 2004.

18. Solomkin JS, Mazuski JE, Baron EJ, Sawyer RG, Nathens AB, DiPiro JT, Buchman T, Dellinger EP, Jernigan J, Gorbach S, Chow AW, Bartlett J. Guidelines for the selection of anti-infective agents for complicated intra-abdominal infections. Clinical Infectious Diseases 37:997-1005, 2003.

19. Steere AC, McHugh G, Suarez C, Hoitt J, Damle N, Sikand VK. Prospective study of coinfection in patients with erythema migrans. Clinical Infectious Diseases 36:1078-1081, 2003.

20. Stevens DL, Bisno AL, Chambers HF, Everett ED, Dellinger P, Goldstein EJ, Gorbach SL, Hirschmann JV, Kaplan EL, Montoya JG, Wade JC. Practice guidelines for the diagnosis and management of skin and soft-tissue infections. Clinical Infectious Diseases 41:1373-1406, 2005. 